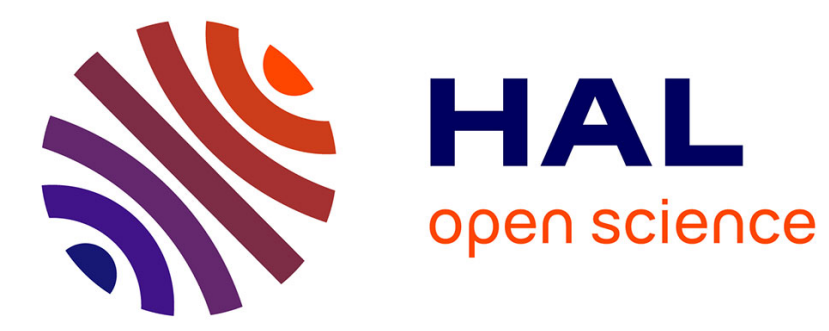

\title{
Origin and migration of woodcock wintering in Spain
}

\author{
Jose Luis Guzmán, Yves Ferrand, Beatriz Arroyo
}

\section{To cite this version:}

Jose Luis Guzmán, Yves Ferrand, Beatriz Arroyo. Origin and migration of woodcock wintering in Spain. European Journal of Wildlife Research, 2010, pp.647-655. 10.1007/s10344-010-0475-9 . hal00655426

\section{HAL Id: hal-00655426 \\ https://hal.science/hal-00655426}

Submitted on 29 Dec 2011

HAL is a multi-disciplinary open access archive for the deposit and dissemination of scientific research documents, whether they are published or not. The documents may come from teaching and research institutions in France or abroad, or from public or private research centers.
L'archive ouverte pluridisciplinaire HAL, est destinée au dépôt et à la diffusion de documents scientifiques de niveau recherche, publiés ou non, émanant des établissements d'enseignement et de recherche français ou étrangers, des laboratoires publics ou privés. 


\title{
Origin and migration of woodcock Scolopax rusticola wintering in Spain
}

\author{
Jose Luis Guzmán • Yves Ferrand • Beatriz Arroyo
}

Received: 11 November 2009 /Revised: 18 October 2010 / Accepted: 22 November 2010 / Published online: 29 December 2010

(C) Springer-Verlag 2010

\begin{abstract}
Woodcock Scolopax rusticola is an important game species in Northern Spain, where it is mainly a wintering species. Knowledge about the migration and origin of the woodcock wintering in Spain is relatively sparse, existing to date only qualitative analyses dating more than a decade. From the analyses of ringing recoveries of woodcock wintering in Spain, we evaluate the relative importance of various countries or regions as sources of the woodcock wintering in Spain, an estimate of their migratory route. Our analyses show the Circum-Baltic Region to be the most important breeding area of the woodcock wintering in Spain. Within that area, both Sweden and Western Russia appear to be particularly important. Analyses of the ringing locations of woodcock ringed during migration and recovered in Spain in winter suggest that woodcock wintering in Spain migrate primarily through the South of the Baltic Sea, Germany and France. The proportion of woodcock ringed in different French regions during the postnuptial migration months (October and November) that was subsequently recovered in Spain (mainly through hunting) declined with the proportion of those birds that was recovered in France (also mainly
\end{abstract}

Communicated by C. Gortázar

J. L. Guzmán $(\bowtie) \cdot$ B. Arroyo

Instituto de Investigación en Recursos Cinegéticos,

IREC (CSIC-UCLM-JCCM),

Ronda de Toledo s/n,

Ciudad Real 13005, Spain

e-mail: Joseluis.guzman@uclm.es

Y. Ferrand

Direction des études et de la recherche,

Office National de la Chasse et de la Faune Sauvage (ONCFS),

5 rue de Saint Thibaud,

St Benoit 78910 Auffargis, France through hunting). We discuss the management implications of these results.

Keywords Management $\cdot$ Migration $\cdot$ Circum-Baltic Region $\cdot$ Ringing $\cdot$ Spain

\section{Introduction}

Migrant game species are usually subject to hunting pressure throughout its migratory route, which may make their management a challenge. Game management is usually regulated at a local or at most national level, but in the case of migratory species, efficient management is only obtained if there is coordination among the countries or regions through which the species passes along the annual cycle. It is thus important to know the connectivity between breeding and wintering areas, as well as migratory routes, to determine which countries should have stronger coherence in the management of these species.

Woodcock Scolopax rusticola is a forest wader with a wide Palaearctic distribution, present throughout temperate areas in Asia and Europe, from the British Isles to Kamtchatka, and from the Arctic Polar Circle to the North of Africa and the Middle East (Cramp and Simmons 1983). The European breeding population spreads from Fennoscandia to the Mediterranean Region (in mountains) and from Western Europe to Eastern Russia (Hagemeijer and Blair 1997). It is a pre-Saharan migrant with a leapfrog migration (Alerstam and Hendenstrom 1998): Populations from Russia and North Europe are mainly migrant, spending the winter from Atlantic to Mediterranean regions and North Africa, while the Southern and Western populations are mainly sedentary, with short-distance migrations (Henderson et al. 1993). Through ring recoveries, it has been shown that populations wintering 
in the UK breed mainly in the Circum-Baltic Region, Norway and Denmark (Hoodless and Coulson 1994), whereas those wintering France breed mainly in Central Russia (Bauthian et al. 2007, Gossmann et al. 1998).

Knowledge about the migration and origin of the woodcock wintering in Spain is relatively sparse, existing to date only qualitative analyses dating more than a decade, which pointed to the Scandinavian countries as their main breeding quarter (Onrubia et al. 1994). This study presents a comprehensive analysis of ringing recoveries made in Spain in winter, in order to obtain a quantitative estimate of the importance of various countries or regions as sources of the woodcock wintering in Spain, as well as an estimate of their migratory route, thus completing the pattern of migration of woodcock for Western Europe. We discuss our results in the context of management of this species.

\section{Methods}

\section{Data sources}

This study is based on the analyses of woodcock ringed in Europe and subsequently recovered in Spain between October and March. These data were obtained from the Central Bureau of Ringing in Europe (Euring), the Centro de Migración de Aves (CMA, Spain), and the Sociedad de Ciencias Aranzadi (Spain). Most of the recoveries (91.1\%) occurred through hunting. Ringing effort (number of woodcock ringed) of France and Russia was obtained through the Office National de la Chasse et de la Faune Sauvage (ONCFS). For other countries, it was obtained through the respective ringing centers. Ringing data correspond to the period 1911-2007 and recoveries to the period 1911-2008.

Both ringing and recovery data were grouped into three periods (breeding, migration, or wintering) according to date. We defined breeding period as April to September and migration period as February-March and October-November (Lucio and Sáenz de Buruaga M 2000; Saari 2006).

We analyzed a total of 244 ringing recoveries, of which 57 corresponded to birds ringed in the breeding period (Table 1) and 187 to birds ringed during migration (Fig. 1).

Origin of the wintering population

To determine the main breeding regions or countries of woodcock wintering in Spain, we considered recoveries of birds ringed during the breeding period $(n=57)$. Initially, we analyzed data at the country level (Table 1). Subsequently, for statistical analyses (and given the low sample sizes), we grouped countries according to geographic location as follows: Circum-Baltic Region, with Sweden, Finland,
Latvia, Estonia, and Western Russia (regions of Pskov and St. Petersburg, Gossmann et al. 1998); Central Russia (regions of Arkangel'sk, Vólogda, Tver, Vladimir, Moscow, Smolensk; Gossmann et al. 1998); Central Europe, with Hungary, Czech Republic, Switzerland, and Germany; Atlantic Coast (Netherlands, Belgium, France) and British Isles (UK and Republic of Ireland).

We calculated the percentage of woodcock recovered from each country/region out of total woodcock ringed there. For all countries except France, we did not have information about the number of birds ringed in each period, so we used total number of birds ringed as an estimate of the effort of ringing during the breeding period. This is probably correct for most of the northern countries, where ringing does not occur in winter. In the case of France (where most ringing occurs during migration and winter), we only considered birds ringed during the breeding period. We tested whether the proportion of woodcock recovered in Spain varied among regions with a Chi-square test. We used the standardized residuals (SR) to look for the significance of each cell. SR higher or lower than 1.95 indicates a significant deviation of the observed from the expected values (Zar 1989). Subsequently, we calculated an index of the importance of each region of country as a source of woodcock wintering in Spain, multiplying the percentage of recoveries by the breeding population estimate in each area and calculating the percent value of the resulting figure.

To analyze the variability in the winter distribution within Spain of woodcock coming from different breeding areas, according to the leapfrog migration described for the species (Alerstam and Hendenstrom 1998), we classed each ringing location during the breeding period in two groups: "short-distance" for locations within the countries closer to Spain (less than 2,000 km from Central Spain: Central Europe countries, France and British Isles) and "longdistance" (more than 2,000 km from Central Spain: Circum-Baltic countries and Russia). We tested with a general linear model whether latitude or longitude of the winter location varied according to the region of origin as described above.

\section{Migratory route}

For the analysis of the migratory route, we considered ringing locations of birds recovered in Spain in winter but ringed during the migration period $(n=187)$. Using the geographical coordinates of all of those locations, we evaluated (through a regression analyses) the equation that best defined the dispersion of those locations using the program Tablecurve 2D v5.01. Of all possible curves describing the dispersion, we chose the one with highest percentage of explained deviance. 
Table 1 Countries where there has been woodcock ringed during the breeding season and subsequent recoveries in Spain during winter

\begin{tabular}{|c|c|c|c|c|c|c|}
\hline Country & Number ringed & Number recovered & Percent recoveries & Breeding population $^{\mathrm{a}}$ & Breeding estimate $^{\mathrm{b}}$ & Index \\
\hline Denmark & 1,968 & 0 & 0.0 & $2,000-3,000$ & 2,500 & 0.0 \\
\hline Norway & $?$ & 2 & $?$ & $30,000-50,000$ & 40,000 & $0.4^{\mathrm{c}}$ \\
\hline Finland & 3,236 & 9 & 0.27 & $100,000-150,000$ & 125,000 & 3.3 \\
\hline Sweden & 1,783 & 17 & 0.95 & $250,000-1,000,000$ & 625,000 & 58.9 \\
\hline Latvia & 388 & 1 & 0.25 & $20,000-30,000$ & 25,000 & 0.6 \\
\hline Estonia & 360 & 1 & 0.27 & $20,000-50,000$ & 35,000 & 0.9 \\
\hline W Russia & 1,986 & 9 & 0.45 & $1,200,000-5,000,000^{\mathrm{d}}$ & $465,000^{\mathrm{e}}$ & 20.8 \\
\hline C Russia & 1,112 & 3 & 0.26 & $1,200,000-5,000,000^{\mathrm{d}}$ & $465,000^{\mathrm{e}}$ & 12.0 \\
\hline Switzerland & 282 & 0 & 0.0 & $1,130-1,630$ & 1,380 & 0.0 \\
\hline Czech Republic & $?$ & 2 & $?$ & $2,000-4,000$ & 3,000 & $0.1^{\mathrm{c}}$ \\
\hline Hungary & 61 & 1 & 1.63 & $10-20$ & 15 & 0.0 \\
\hline Germany & $?$ & 0 & 0.0 & $12,000-24,000$ & 18,000 & 0.0 \\
\hline Netherlands & $?$ & 1 & $?$ & $2,000-3,000$ & 2,500 & $0.1^{\mathrm{c}}$ \\
\hline Belgium & 811 & 4 & 0.49 & $1,600-2,800$ & 2,200 & 0.1 \\
\hline France & 153 & 2 & 1.31 & $10,000-30,000$ & 20,000 & 2.6 \\
\hline British Isles & 9,862 & 5 & 0.05 & $7,900-23,700$ & 15,800 & 0.1 \\
\hline
\end{tabular}

Index represents the estimated proportion of woodcock wintering in Spain coming from each country or region

${ }^{a}$ BirdLife International (2004)

${ }^{\mathrm{b}}$ Median of the estimate in the previous column

${ }^{\mathrm{c}}$ Calculated with estimates of $0.1 \%$ recoveries for Norway, $0.4 \%$ recoveries for Czech Republic, and 0.6 for the Netherlands (these figures represent the average for the countries in each group, except for Norway, where we added a minimum of 0.1 as there exist some recoveries)

${ }^{\mathrm{d}}$ For the whole of Russia

${ }^{\mathrm{e}}$ Estimated as $15 \%$ of the median for the whole of Russia

Fig. 1 Ringing location of woodcock recovered in Spain during winter, according to ringing time (breeding period: filled circles; migration: open circles)

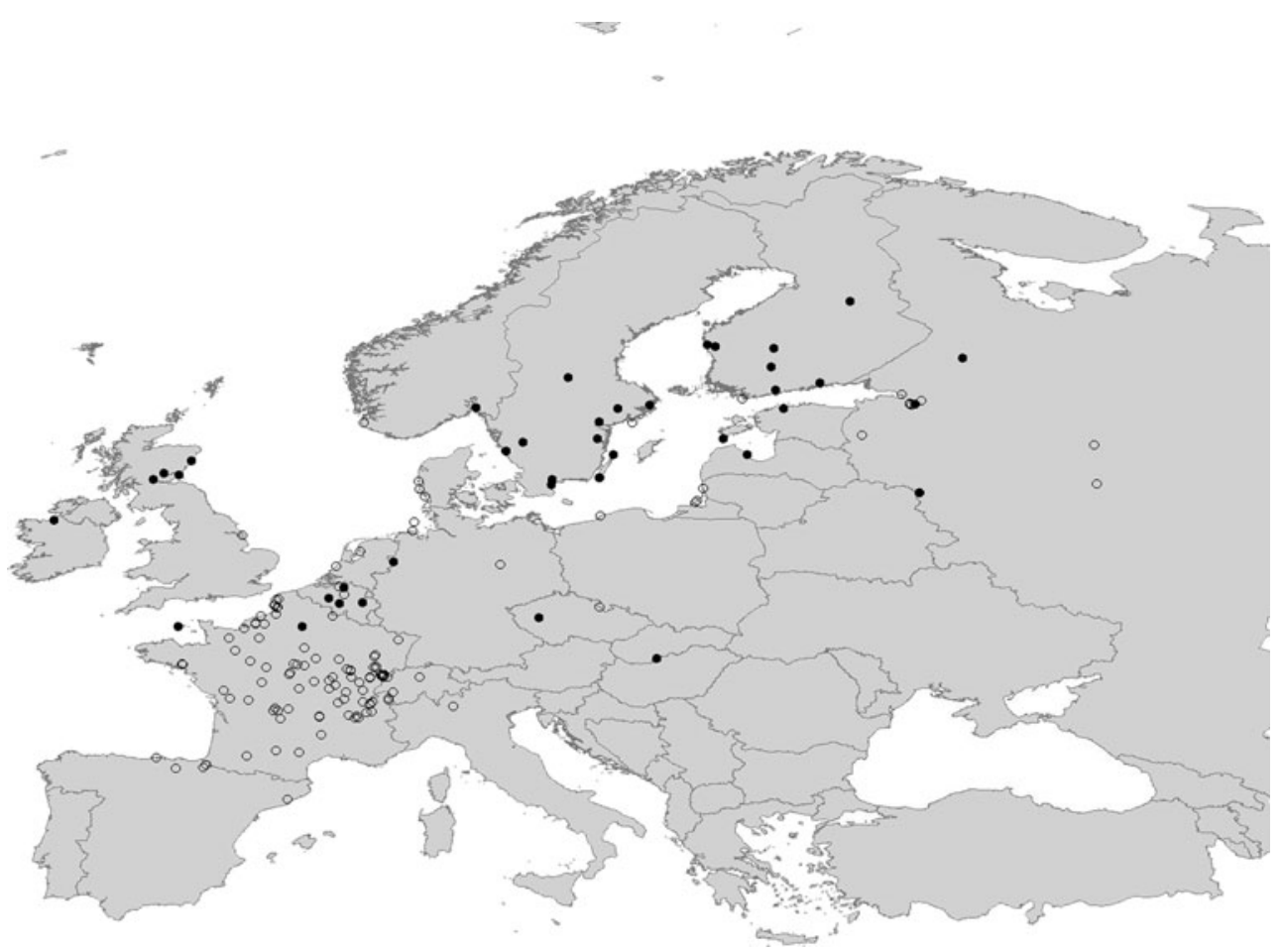


A more detailed analysis of spatial and temporal migration variation through France may be of interest, as it has implications for management. For example, ringing data may give indications about timing of spring migration through France, which are relevant for regulating closure of hunting seasons there, and determining whether certain French regions are particularly important as a migratory flyway for woodcock wintering in Spain is also useful as hunting pressure varies strongly among regions there. To analyze the spatial and temporal variation of movements within France, we analyzed data of birds ringed in France during migration or wintering months, and subsequently recovered in Spain, by month and region of ringing. Regions were defined as in Bauthian et al. (2007) (Fig. 2). We used Chi-square tests, and SR to look for the significance of each cell.

\section{Results}

Origin of the wintering population

Overall, the proportion of woodcock ringed during the breeding period and recovered in Spain during winter varied significantly with ringing region $\left(X_{4}^{2}=53.78, P<0.001\right)$ : woodcock coming from the Circum-Baltic Region and the
Atlantic Coast were recovered in Spain more frequently than expected, whereas the opposite was observed for woodcock coming from the British Isles (Table 2). Taking into account breeding population size, it would appear that more than $80 \%$ of the woodcock wintering in Spain would breed in the Circum-Baltic Region (including Western Russia) (Table 1).

Figure 3 suggests a different distribution of birds of different origin within Spain, with the most western and southern recoveries corresponding to long-distance migrants and short distance migrants being restricted to northern and eastern areas. However, neither longitude nor latitude of the winter location varied significantly between both groups ( $F_{1,55}=0.10, P=0.7$ for latitude; $F_{1,55}=0.47, P=0.5$ for longitude).

Migratory route

\section{General migratory route}

Figure 4a shows the modeled curve from the distribution of locations of woodcock ringed during migration and subsequently recovered in Spain in winter $(n=187)$. This curve explained $58 \%$ of the variance and suggests that woodcock wintering in Spain probably pass primarily close to the South of the Baltic Sea and subsequently through Germany and France.

Fig. 2 Regions in France used for analyses (modified from Bauthian et al. 2007)

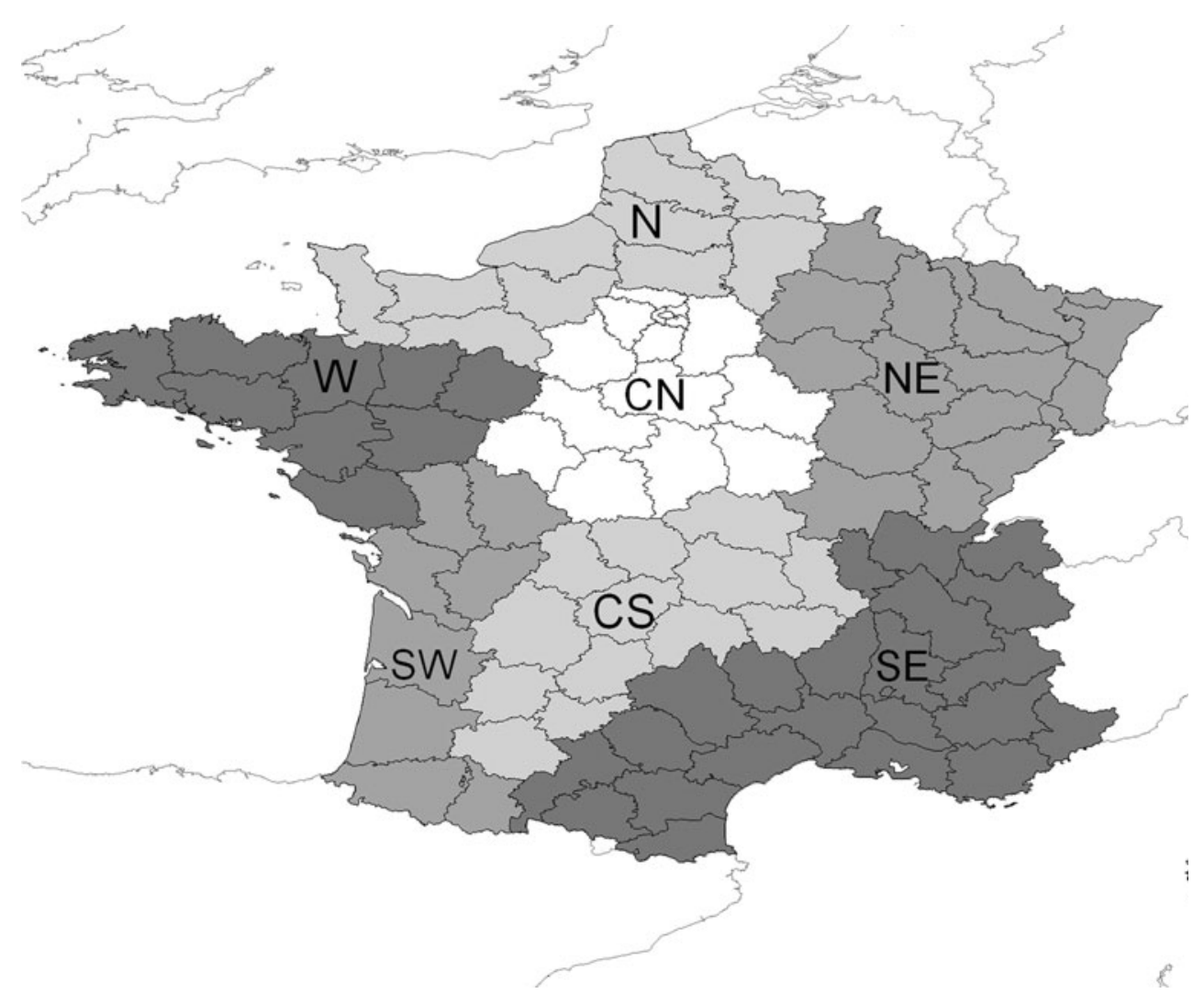


Table 2 Proportion of woodcock ringed in various regions and subsequently recovered in Spain during winter

\begin{tabular}{llllr}
\hline Region & $\begin{array}{l}\text { Number } \\
\text { ringed }\end{array}$ & $\begin{array}{l}\text { Number } \\
\text { recovered }\end{array}$ & $\begin{array}{l}\text { Percent } \\
\text { recoveries }\end{array}$ & SR \\
\hline Circum-Baltic & 5,767 & 37 & 0.64 & 4.87 \\
Central Russia & 1,112 & 3 & 0.26 & -0.15 \\
Central & 343 & 1 & 0.29 & -0.01 \\
$\begin{array}{c}\text { Europe } \\
\text { Atlantic Coast }\end{array}$ & 964 & 6 & 0.62 & 3.17 \\
British Isles $^{\mathrm{b}}$ & 9,862 & 5 & 0.05 & -4.46 \\
\hline
\end{tabular}

$S R$ standardized residuals of the Chi-square test

${ }^{a}$ Data from Germany or Czech Republic not included since no ringing effort was available

${ }^{\mathrm{b}}$ Data from Netherlands not included since no ringing effort was available

\section{Temporal and spatial variation through France}

Not surprisingly, the probability of recovering in Spain woodcock ringed in France varied significantly according to ringing month $\left(X_{5}^{2}=33.03, P<0.001\right)$, being significantly higher than expected for October and November and significantly lower than expected for January and February (Table 3).

The probability of recovering in Spain woodcock ringed in France during the postnuptial migration months (October and November) also varied significantly according to ringing region $\left(X_{5}^{2}=19.4, P<0.005\right)$ : Recoveries in Spain are higher than expected for birds ringed in the $\mathrm{NE}$ and $\mathrm{CN}$ regions and lower than expected for the Western Region (Table 4). There was a negative correlation between the percentage of woodcock ringed in each French region during the postnuptial migration months that is subsequently recovered in Spain and the percentage of those woodcock subsequently recovered in France (Fig. 5, $r=-0.906, P<0.0001$ ).

\section{Discussion}

Origin and distribution of woodcock wintering in Spain

Our analyses indicate that the Circum-Baltic Region is the most important breeding area of woodcock wintering in Spain. Within that area, both Sweden and Western Russia appear to be particularly important (although it is important to remark that maybe the difference between Central and Western Russia is not as clear as we present here: as the ringing effort in this area takes place in September, when postnuptial migration may have started, some of the birds ringed in Western Russia may have originated further east, e.g., in Central Russia). Woodcock breeding along the Atlantic Coast would also have a relatively high probability of wintering in Spain, but given the lower importance of the breeding populations in those countries, the total contribution to the wintering population in Spain would be lower. Finally, birds breeding in the British Isles and Central Europe would only occasionally winter in Spain.

These data fit among those described for the British Isles (Hoodless and Coulson 1994), which indicate a strong

Fig. 3 Recovery location of woodcock coming from short-distance countries (filled circles) or long-distance countries (white circles)

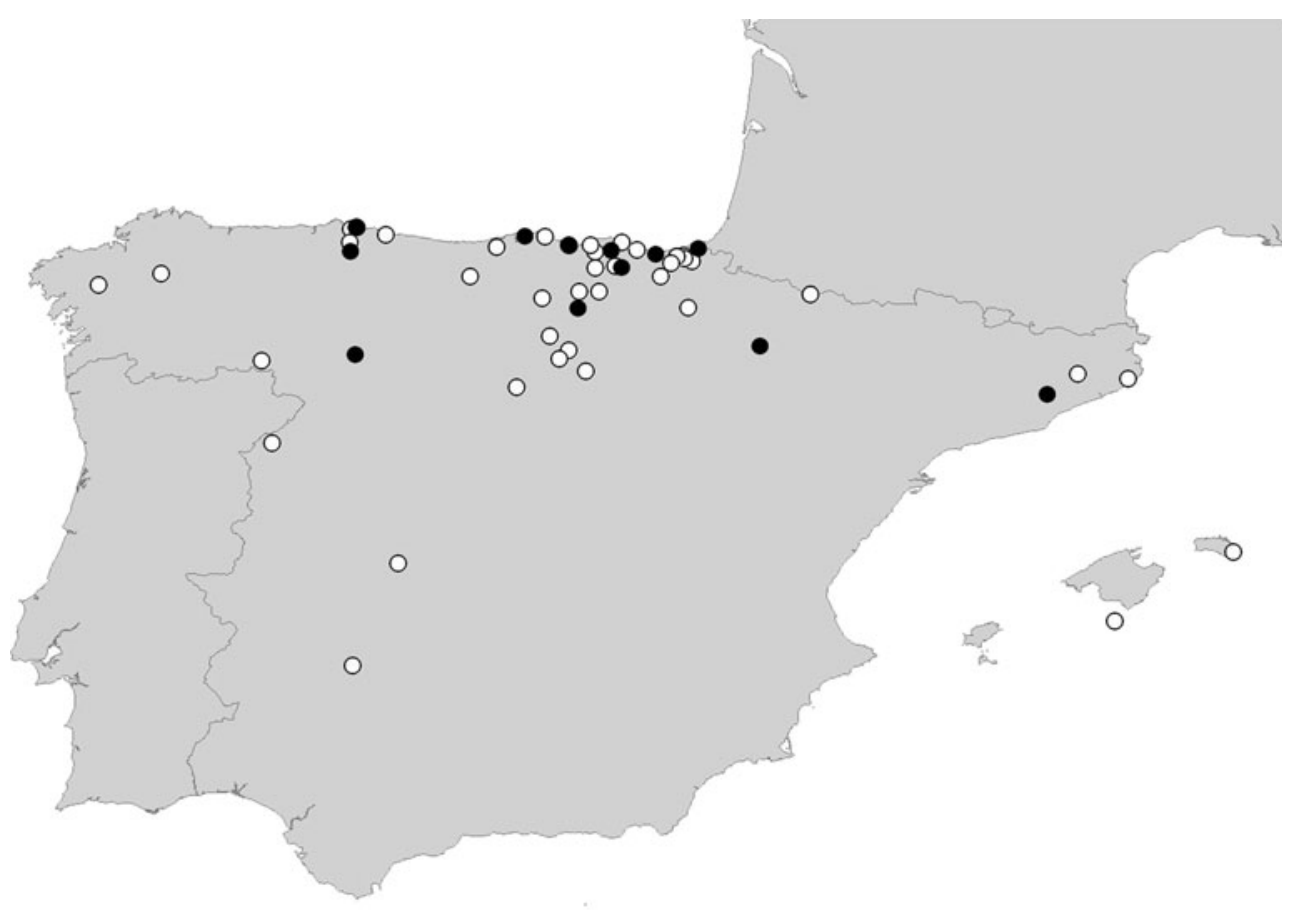


Fig. 4 a Modeled migratory route of the woodcock wintering in Spain. Filled circles, best fit curve; open circles, $95 \%$ confidence limit; open triangles, $95 \%$ prediction limits.

b Best-quality locations of two woodcock tagged with satellite transmitters by the Spanish Woodcock Hunting Club (CCB). Data obtained from March to May 2009 and kindly made available to us by $\mathrm{CCB}$
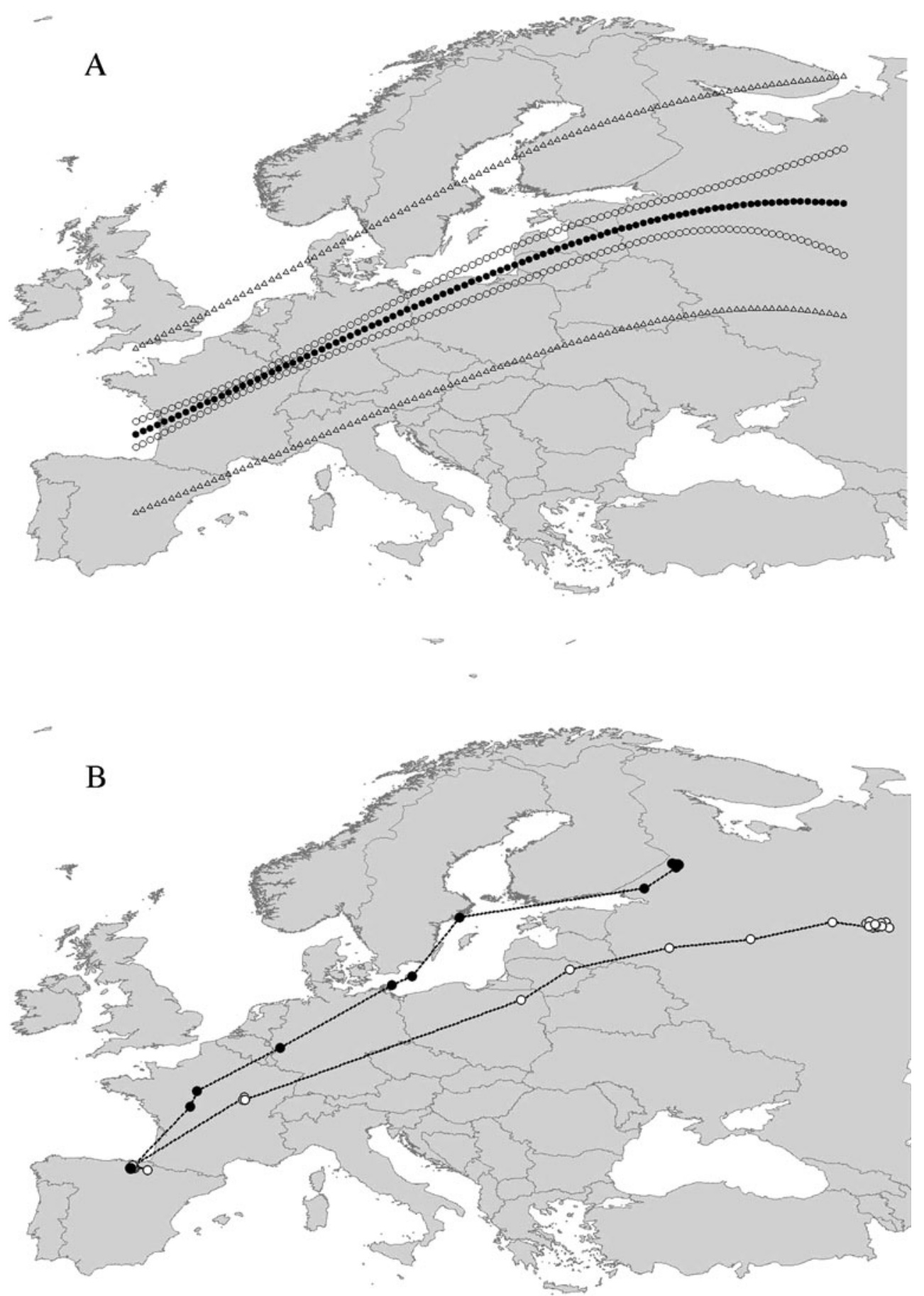

preponderance of the Circum-Baltic and Scandinavian regions as origin for the woodcock wintering in that area, and those described for France (Gossmann et al. 1998; Bauthian et al. 2007), where ringing data showed a stronger importance of the centre of Russia as origin of the French wintering woodcock. Hence, our analyses complete the general migratory pattern of woodcock in Western Europe, suggesting a strong longitudinal gradient among breeding and wintering areas, with birds breeding further east wintering also further east.
On the other hand, we did not find any firm evidence that woodcock coming from different breeding areas had different wintering distribution within Spain, although lack of statistical differences may be due to the small sample sizes, so this issue merits further attention.

\section{Migratory routes and timing}

Analyses of the ringing locations of woodcock ringed during migration and recovered in Spain in winter suggest 
Table 3 Proportion of woodcock ringed in France and subsequently recovered in Spain according to ringing month

\begin{tabular}{llllr}
\hline Ringing month & Number ringed & $\begin{array}{l}\text { Number } \\
\text { recovered }\end{array}$ & $\begin{array}{l}\text { Percent } \\
\text { recoveries }\end{array}$ & SR \\
\hline October & 1,715 & 9 & 0.52 & 2.72 \\
November & 16,144 & 51 & 0.32 & 2.67 \\
December & 14,796 & 30 & 0.20 & -0.39 \\
January & 10,191 & 6 & 0.06 & -3.44 \\
February & 6,763 & 7 & 0.10 & -2.02 \\
March & 5,003 & 16 & 0.32 & 1.54 \\
\hline
\end{tabular}

$S R$ standardized residuals of the Chi-square test

that woodcock wintering in Spain migrate through a route closer to the Baltic Sea than to Central Europe, in accordance with the above-mentioned results. These results also coincide with those obtained from various woodcock tagged with satellite transmitters since 2007 (see Fig. 4b), arising from a study by the Spanish Woodcock Hunting Club (CCB) (http://rtvs.ccbp.org/).

A previous study determined the existence of two migratory routes for woodcock wintering in France, one going through Fennoscandia and another one through Eastern Europe (Bauthian et al. 2007). This study was based on birds ringed in winter in France and subsequently recovered (mainly through hunting) along the migratory route. Our study, in contrast, in based on the ringing location of birds recovered in Spain. This implies that the importance of certain countries in the migratory route may be hidden if they do not have woodcock ringing programs, as is the case in many Eastern Europe countries. It is therefore plausible that woodcock arrive to Spain also through two migratory routes, including another eastern one, although this will need to be confirmed in further studies.

France is a compulsory corridor for the woodcock wintering in Spain, and more than $40 \%$ of all ringing

Table 4 Percentage of woodcock ringed in France in OctoberNovember and subsequently recovered in Spain according to ringing region (see Fig. 2)

\begin{tabular}{llllr}
\hline $\begin{array}{l}\text { Ringing } \\
\text { region }\end{array}$ & $\begin{array}{l}\text { Number ringed in } \\
\text { October-November }\end{array}$ & $\begin{array}{l}\text { Number } \\
\text { recovered }\end{array}$ & $\begin{array}{l}\text { Percent } \\
\text { recoveries }\end{array}$ & SR \\
\hline W & 4,541 & 2 & 0.04 & -2.75 \\
SW & 2,969 & 6 & 0.20 & -0.49 \\
NE & 3,856 & 17 & 0.44 & 2.43 \\
SE & 3,562 & 11 & 0.31 & 0.75 \\
N & 5,179 & 12 & 0.23 & -0.22 \\
CN & 1,303 & 7 & 0.54 & 2.11 \\
CS & 2,906 & 5 & 0.17 & 0.81 \\
\hline
\end{tabular}

$S R$ standardized residuals of the Chi-square test

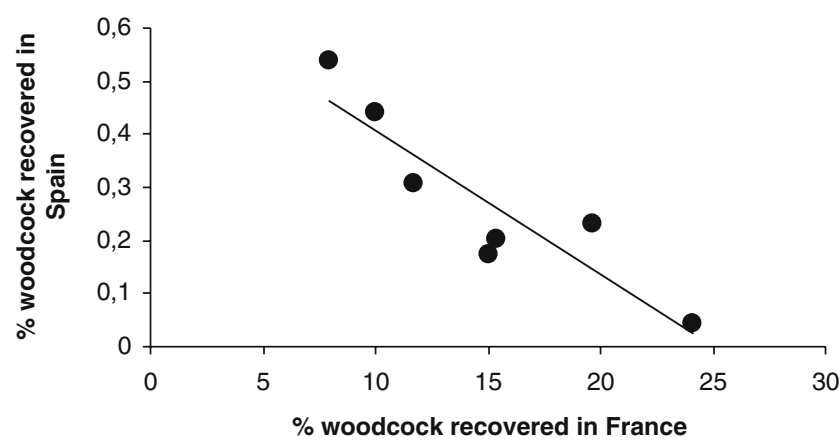

Fig. 5 Relationship between the percentage of woodcock ringed in each French region during the postnuptial migration months (OctoberNovember) that are recovered subsequently (mainly through hunting) in either Spain or France

recoveries in Spain belonged to birds ringed in France in migratory months. According to our results, the probability of recovering woodcock ringed during migration in western regions is lower than elsewhere, suggesting that there may be a lower migratory flux through those regions (as also suggested from Fig. 4). Recoveries from north-central and north-eastern regions were more common than expected by chance, which is also in accordance with the general migratory flux. In contrast, it was surprising that southwestern or central-southern regions were not significant. Alternatively, this pattern may be related to the spatial variation in hunting effort within France. The negative correlation found between the probability of recovery in France and Spain of woodcock ringed during the migrating months in different French regions supports this hypothesis. It is thus possible that hunting pressure suffered by migrating woodcock in France affects the populations wintering in Spain. However, it is important to interpret these results with caution, because they are just correlations, not causal relationships. It would be important to do more detailed studies to evaluate the relative importance of the heterogeneous passage through France and the influence of hunting pressure on wintering populations in Spain.

The analysis of temporal variation in probability of recovery indicates that the peak of post-breeding migration through France occurs in October and November and that pre-breeding migration through France does not occur before March. These results agree with the average departure dates (October 10) and arrival dates (9 May) observed in Southeastern Finland (Saari 2006), as well as with migration data suggested for Spain based on ICAs (Lucio and Sáenz de Buruaga M 2000). Similarly, these data are coherent with observed departure dates (to throughout March) from Spain toward breeding grounds obtained from satellite transmitters and for radio-tracked woodcock in Northern Spain (Guzmán and Arroyo, unpublished data). 
Management implications

As the main source of woodcock wintering in Spain appears to be the Circum-Baltic Region (particularly Sweden and Western Russia), it would be particularly important to establish connections between those countries, in order to include productivity in those regions in the hunting management in Spain. For example, hunting bags could be cupped up in relation to the productivity in those regions. In a recent study, spring temperature in Norway appeared to be a good predictor of woodcock hunted in that country in early autumn (Selas 2006), which would point to spring temperature as a potential predictor of woodcock productivity. If verified, this could be an interesting management tool, allowing the determination of various scenarios ("good" or "poor" reproduction years) and thus various degrees of hunting bag limits.

Looking at the countries that form part of the migratory route of woodcock wintering in Spain (according to results in this study) and the duration of the hunting season in those countries (Lutz and Jensen 2006), woodcock wintering in Spain are apparently hunted throughout the annual cycle, except in June, July, and March. For example, in countries like Russia, Lithuania, and Latvia, hunting is practiced in April and May (Ferrand and Gossmann 2001; Blokhin and Fokin 2005), which would include part of the pre-breeding migration and the breeding period, when hunting is prohibited in European Union according to Annex II of the Birds Directive (European Commission 2004).

According to old estimations, France could be responsible about $25 \%$ of all woodcock hunted in the European Union (Ferrand and Gossmann 2001). However, appropriate bag estimates for Spain are lacking, so the impact of hunting pressure in Spain on woodcock populations is unknown. In any case, France is a compulsory corridor for woodcock wintering in Spain, and Spain is a refuge for French wintering woodcock when they move south in cold spells (Gossmann and Ferrand 1998). Thus, coordination between both countries seems critical for the long-term and sustainable use of the species. Additionally, it would be important to determine the effect of different management guidelines on populations. One example is the dates of hunting closure implemented in Spain (early or late January, depending on regions) and France (where hunting is allowed until February 20) (Lutz and Jensen 2006). Hunting in February in France has been a source of conflict in Spain, as it could include migratory birds. Our results suggest that pre-breeding migration of woodcock wintering in Spain occurs mostly in March, so hunting in February in France should not have a strong impact on Spanish wintering woodcock. In contrast, the data above suggest that hunting in the autumn in western regions may be having an impact on the Spanish wintering population. Future studies should address the effect of different management guidelines on populations.

Acknowledgments This study has been funded by the Comité Interautonómico de Caza y Pesca Continental in Spain and has been carried out within the Framework of the Interregional Study on Woodcock Scolopax rusticola in Spain (project number 200430E471). We thank the staff in ringing offices that provided woodcock ringing data: Chris du Feu (EURING Data Bank), Óscar Frías (Oficina de Especies Migratorias, Dirección General para la Biodiversidad, Ministerio de Medio Ambiente), Ainara Azkona (Oficina de Anillamiento de Aranzadi), Kaarel Kaisel (Estonia), Jacquie Clark (British Trust for Ornithology), Juris Kazubiernis (Letonia), Jari Valkama (Finlandia), Dr Thord Fransson (Bird Ringing Centre, Swedish Museum of Natural History), and Didier Vangeluwe (Institut Royal des Sciences Naturelles de Belgique, Centre Belge de Baguage). Additionally, we are grateful to all the Spanish ringers that contributed to the project: David Lizaso, Miguel San Martín, Alberto Artácoz, Felipe Oiarzabal, Iñaki Balda, Peio Oiarzabal, Juan Jesús Picabea, Nestor Domeño, Iñaki Ripa, Angel María Sarratea, Eduardo Sarratea, Javier Oiaregui, Ion Aldunzin, Fernando Belzunce, Rafael López de Aberasturi, Jesús Gutierrez, Melchor Alzugara, Agustín Mendiburu, Mikel Olano, Esteban Iriarte, Alejandro Onrubia, Ibón Telletxea, Javier Monge, Pedro Zuleta, Marco Escudero, José Luis Rivas, Javier Lucientes, Carlos Pérez, Javier Ferreres, Rubén Ibáñez, Marco Escudero, Marc Palles, Celestino Suarez, Miguel González-Vélez, Justo José Robles, and Pablo González. Enrique Castién provided useful comments on the manuscript.

\section{References}

Alerstam T, Hendenstrom A (1998) The development of bird migration theory. J Avian Biol 29:343-369

Bauthian I, Gossmann F, Ferrand Y, Julliard R (2007) Quantifying the origin of woodcock wintering in France. J Wildl Manage 71 (3):701-705

BirdLife International (2004) Birds in Europe: population estimates, trends and conservation status. BirdLife conservation series 12 . BirdLife International, Cambridge

Blokhin Y, Fokin S (2005) Different methods for the estimation of the woodcock hunting bags in Russia. WI-WSSG Newsletter 31:4-9

Cramp S, Simmons KEL (1983) Handbook of the birds of Europe, the Middle East and North Africa, III Waders to Gulls. Oxford University Press, Oxford, pp 444-457

European Commission (2004) Guidance document on hunting under Council Directive 79/409/EEC on the conservation of wild birds «The Birds Directive».

Ferrand Y, Gossmann F (2001) Elements for a woodcock (Scolopax rusticola) management plan. Game Wildl Sci 18(1):115-139

Gossmann F, Ferrand Y (1998) Impact of the 1996-97 cold spell on Woodcock in France based on ring recoveries. Fifth European Woodcock and Snipe Workshop, pp. 37-39.

Gossmann F, Fokin S, lljinski I (1998) Ringing of woodcock in Russia from 1991 to 1997. Fifth European Woodcock and Snipe Workshop: 10-14.

Hagemeijer W, Blair M (1997) The EBBC atlas of European breeding birds. Their distribution and abundance. EBCC \& AD Poyser, London, p 903 
Henderson IG, Peach WJ, Baillie SR (1993) The hunting of snipe and woodcock in Europe: a ringing recovery analysis. British Trust for Ornithology, Thetford

Hoodless AN, Coulson JC (1994) Survival rates and movements of British and continental woodcock Scolopax rusticola in the British Isles. Bird Study 41:48-60

Lucio A, Sáenz de Buruaga M (2000) La Becada en España. Fedenca, $174 \mathrm{pp}$.

Lutz M, Jensen FP (2006) European Union management plan for woodcock Scolopax rusticola. 2007-2009. European Commission, unpublished report.
Saari L (2006) Spread of the woodcock Scolopax rusticola to finnish Lapland. WI-WSSG Newsletter 32:22-28

Onrubia A, Lucio A J, Sáenz de Buruaga M, Campos MA (1994) La Caza de la Aves Migrantes en el Territorio Histórico de Bizkaia. Diputación Foral de Bizcaia. Informe inédito: 99110.

Selas V (2006) Patterns in grouse and Woodcock Scolopax rusticola hunting yields from central Norway 1901-24 do not support the alternative prey hypothesis for grouse cycles. Ibis 148:678-686

Zar JH (1989) Biostatistical analysis. Prentice-Hall, London 